SCIREA Journal of Hydraulic Engineering http://www.scirea.org/journal/Hydraulic

December 14, 2021

SCIREA

Volume 4, Issue 3, June 2021

https://doi.org/10.54647/hydraulic57026

\title{
Lessons Learned From Low-Crested Breakwaters Installation in North Coast of Java
}

\author{
SULAIMAN, DM ${ }^{1,}$ *, F. NURHABNI ${ }^{2}$, H.BACHTIAR ${ }^{3}$ \\ ${ }^{1}$ Ministry of Public Works and Housing, Bandung - INDONESIA \\ ${ }^{2}$ Ministry of Marine and Fisheries Affair, Jalan Medan Merdeka Timur No.16 Jakarta - \\ INDONESIA \\ ${ }^{3}$ Ministry of Public Works and Housing, Pangkal Pinang - INDONESIA \\ Email address: dedems@ymail.com (SULAIMAN, DM) \\ ${ }^{*}$ Corresponding author
}

\begin{abstract}
:
Beyond the boundary and design criteria of Low Crested Breakwater (LCB), the success of LCB applications largely depends on the layout of the breakwater installation. The configuration of LCB includes vertical and horizontal positioning. Vertical layout related to the peak elevation position of the structure to the sea level, both to Mean Sea Level (MSL) and High Water level (HWL). Horizontal layout connected with LCB installation related to the optimal distance from the shoreline, the length of the structure, and the width of the gap between LCBs. These three parameters determine sediment volume accumulated behind LCB. This paper presents a summary of field experiences that is expected to be useful for the development of LCB as one of the methods of coastal protection. The objective of developing LCB structure is to make LCB concept as preferred coastal structure that is applicable to all types of materials commonly used for coastal protection.
\end{abstract}


Keywords: Low-Crested Breakwaters, geotextile tube, beach erosion, coastal protection, North Coast of Java.

\section{Introduction}

The North Coast of Java is an example of coastal ecosystems that experiencing coastal degradation due to long term period of improper management of the coastal areas. Conversion of mangrove into fishponds and settlement lead to various impacts such as siltation, coastal erosion, pollution, high tide induced flooding, declining fisheries productivity and various social problems. Climate change that occurs globally also gives a tremendous impact on coastal areas. The increase of sea water level causing coastal areas with sloping contours which can be inundated by sea water. In order to countermeasure coastal erosion, the government has installed low-crested protection structures made of geotextile tube material. LCB geotextile tubes has been deployed along the North Coast of Java from Tuban in East Java to Karawang in West Java Province with the length approximately $25 \mathrm{Km}$ of (Figure 1).

LCB's research and development activities have been started since 2009. A physical model test in the laboratory initially was carried out and it was followed by LCB prototype model test in the field. The objective of this research activity is to get coastal protection technology in an effective, efficient, and having environmental friendly way. A total of ten LCB prototypes made of geotextile tube (geotextile tube) material and have been applied in three different coastal types. White sandy beach, Anyer, represents sandy beach with high wave conditions and a rather steep coastal slope. Tanjung Kait Beach, Tangerang, Banten Province, represents sandy sloping beaches with relatively calm wave conditions. While the beach Pisangan, Karawang, used as a test for a muddy beach with medium wave height. The first LCB implementation by Local Government of Pekalongan City along $5.5 \mathrm{Km}$ of Sari Beach, Slamaran beach, and Muara Rejeki beach in 2012 (Basyir Ahmad et al., 2015). Furthermore, the Marine and Fisheries Agency of Batang Regency, Central Java in 2014 and 2015 had installed LCB geotextile tube to overcome erosion in Sigandu Beach (Sulaiman et al., 2015a). Until 2016, the Ministry of Marine Affairs and Fisheries, had installed $12.6 \mathrm{~km}$ Beach Belt long from geotextile sack, which is another name of LCB geotextile tube along the North Coast of Java (MMAF, 2016). 
This paper is a lesson learned from several applications and field experiences in an effort to obtain an effective, affordable, and environmentally friendly coastal protection method. The ultimate goal of the development of LCB structures is to make LCB as a preferred coastal protection method that is capable of controlling and restoring coastal damaged into stable conditions with affordable cost.

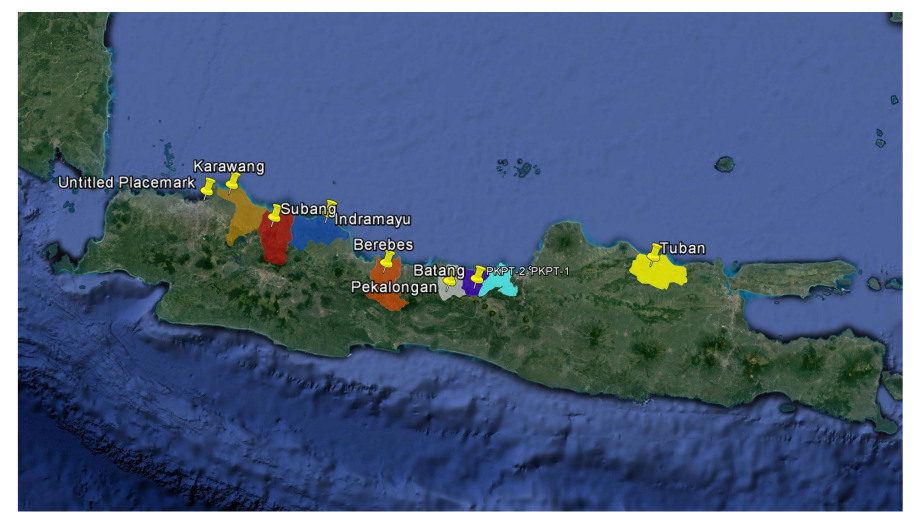

Fig. 1. Location of geotextile tube LCBs along the North coast of Java (Google Earth, 2017)

\section{Methodology}

\subsection{Physical and Numerical Model Test}

Physical model test was conducted at JTSL Hydraulics Laboratory Gadjah Mada University, Yogyakarta. The model tests were conducted to determine the effect of LCB elevation on wave transmission and coastal response behind the structure. The type of material used consists of geotextile tubes and rubble mounds. The test results show that the coastal response formed behind the structure is much influenced by the freeboard, the distance of the structure from the shore, and the wave height.

In numerical experiments model test, the study of the existence of LCB structure to the current pattern, wave transmission, and coastal profile is performed by MIKE 21 . The module used is MIKE $21 \mathrm{SW}$ (Spectral Wave) for wave model, MIKE 21 HD FM (Bathimetry Meshing) for Current patterns, and MIKE 21 FM ST for sediment transport. The numerical modeling is also to determine the best formation of the LCB structure to be installed in relation to the emerging current pattern and the coastal response to be formed behind the LCB (Figure 2). 

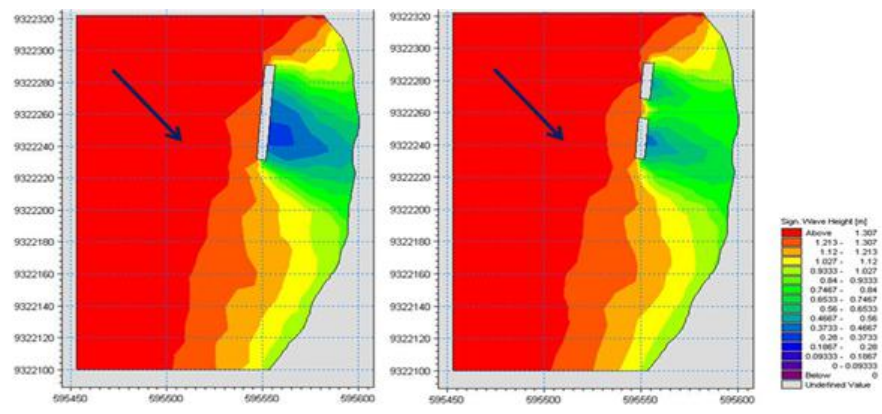

Fig. 2. Numerical Model for Current and Wave for Single and Segmented LCB (Sulaiman et.al, 2012)

\subsection{Deploying LCB Geotextile tube alomg North Coast of Java}

LCB prototype has been implemented in three coastal locations, namely Pasir Putih, which is located in Anyer beach, Tanjung Kait beac inTangerang District, and Pisangan beach in Karawang District. The geotextile tube LCB prototype on the Anyer coast is carried out in two phases, ie Phase 1 done on December 2010 with three pieces of geotextile tube LCB installed with a gap at low water level (LWL) position. While the Phase 2 installation was carried out in November 2011, two LCB geotextile tube prototypes were installed on average water level (MSL) $50 \mathrm{~m}$ from the shore.

The installation of LCB geotextile tube prototypes at Tanjung Kait beach was conducted on May 2011 to represent sloping beaches with relatively low wave climate conditions, LCB geotextile tube installed at a position about $20 \mathrm{~cm}$ above average water level. A total of 3 pieces of geotextile tube LCB were installed with a gap of $10 \mathrm{~m}$ at a distance from the coast about $120 \mathrm{~m}$. The geotextile tube LCB condition after six months of installation is shown in Figure 3.
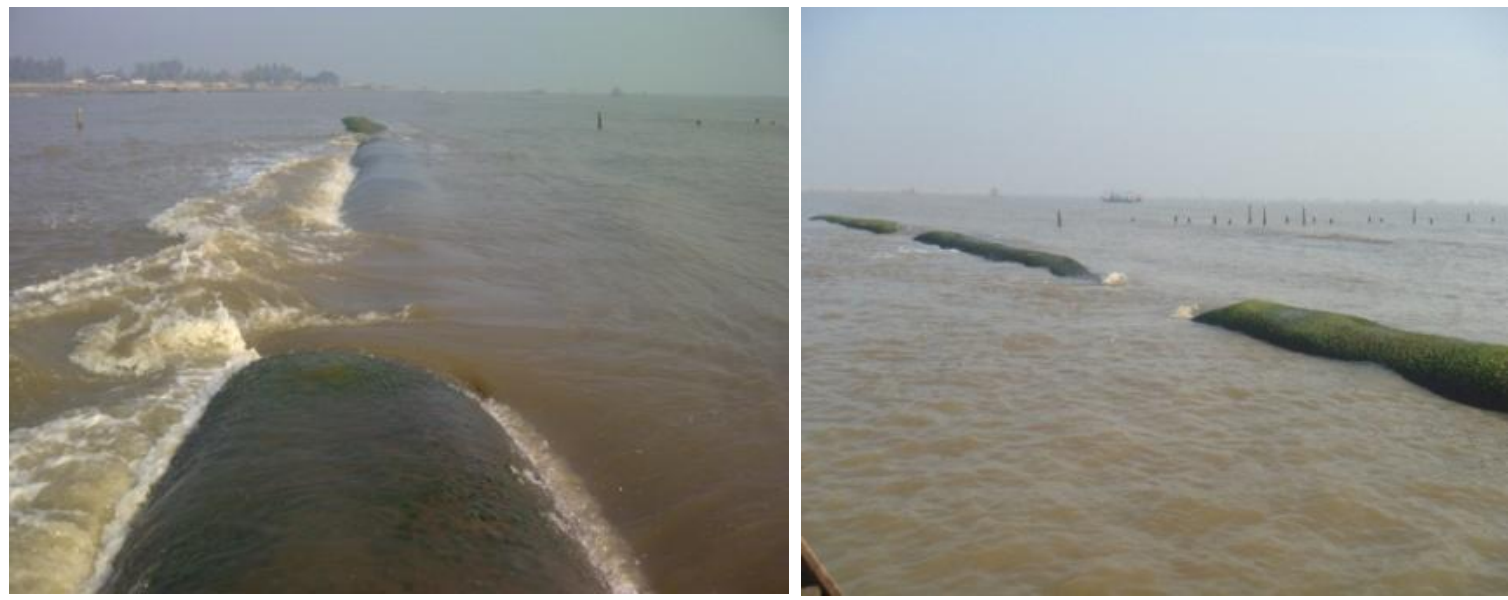

Fig. 3. LCB geotextile tube in Tanjung Kait Beach (Sulaiman et.al., 2012). 


\section{Field Experiences and Discussion}

\subsection{LCB vertical layout}

The LCB function is to force a breaking wave and let the wave to be transmitted so that a calm wave condition occurs behind the structure. The sediment transport capacity behind LCB is also reduced, which means that sand will accumulate. Runoff also shows the presence of water mass transport over the structure. There is a strong correlation between wave transmission, mass transport above the structure, and reduced sediment transport. In addition the wave parameters such as wave height, period, and steepness, LCB geometry, such as threshold distance, distance from shore, and length of structure also play a significant role in determining its effectiveness. Therefore, LCB design positioning determines the purpose and usefulness of LCB construction.

\subsubsection{As stabilizer and sand stopper}

When we use beach stabilizer and sand stopper, the LCB placement should be designed and placed in a low water level (LWL) position. The LCB position of the Pasir Putih beach, Anyer against the water level is shown in Figure 4. The submergency degree of the LCB is very influential both on wave transmission and on the coastal profile formed behind the structure. In the installation of LCB geotextile tube Phase I, which is on December 2010, the placement of three LCB units was conducted at low sea level elevation. In such LWL positions, the breakwater building includes fully submerged about six months after installation, the three LCB have been buried in sand and formed a new beach profile (Sulaiman et al., 2012). The coastal conditions around the LCB show a sloping profile that indicates stable coastal conditions..

The results of monitoring LCB conditions after two years installation indicate that the presence of all three LCBs has been buried in sand sediments, but the coastal profile behind the structure appears stable and sloping. The sedimentation process and the formation of stable beaches behind the LCB Anyer can be analyzed that sediments derived from coastal shipping, when transported back to the offshore, the sediments are obstructed and settle behind the LCB structure. Within a period of 6 months until the last monitoring of March 2013, the sediment covered the entire LCB body. The coastal profile formed between the LCB's location toward the coast shows a stable beach. In other processes, the reflection wave that occurs in front of the LCB structure causes local scouring and slowly leads to instability 
and subsequent settlement and accumulated sand from onshore-offshore and longshore transport.

\subsubsection{Coastal erosion controller}

The effectiveness of LCB in returning eroded beaches is strongly influenced other than wave parameters, also by geometry of LCB structures, especially threshold distances, distance from shore, and length of structure. Hanson and Kraus (1991) show that the shoreline response to the presence of breakwaters is controlled by at least 14 variables, eight of which are highly variable (1) distance from the coast; (2) the length of the structure; (3) the height and the width of the light; (4) coastal slope; (5) wave height, (6) wave period; (7) the angle orientation of the structure; And (8) the direction of the dominant wave. A practical approach to producing an effective LCB for erosion control and beach shore is to place the LCB structure in a position above MSL. LCB prototypes of Tanjung Kait beach (Sulaiman et.al., 2012) as presented at Figure 3, geotextile tube LCB of Sari beach, Pekalongan (Basyir Ahmad dkk., 2015) as showed on Figure 5, Sigandu beach (Sulaiman et al, 2015b) as presented on Figure 6, and Pasir Putih beach Karawang (MMAF, 2016) as presented on Figure 7, are LCB structures with crest level between the mean sea level and the highest water level (Figure 4). The geotextile tube LCB at the coastal site provides a positive coastal response that formed salient or tombolos, which is a new beach formed by LCBs.

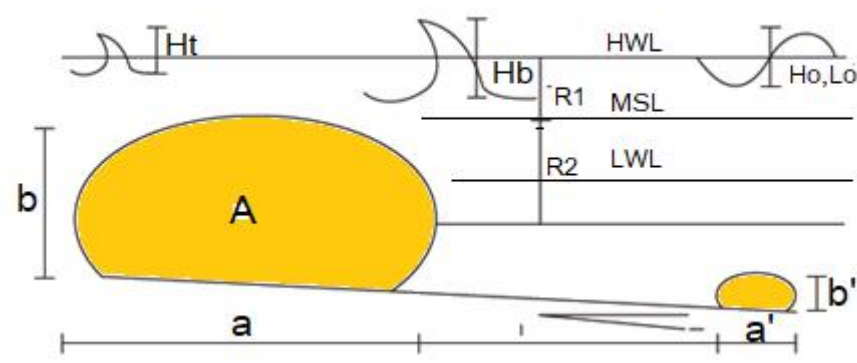

Fig. 4. Crest level of LCB At Mean Sea Level (Adopted from Alvarez et.al., 2006). 

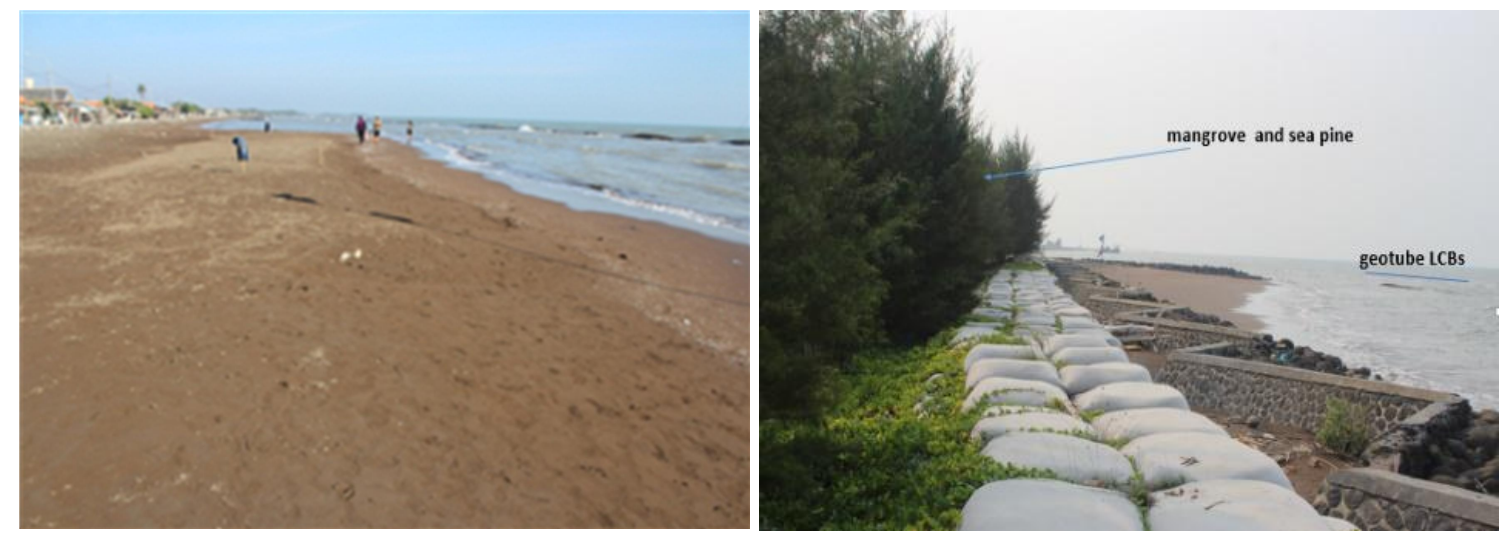

Fig. 5. LCB geotextile tube and the Result in Sari Pekalongan Beach (Ahmad et.al.,2015).
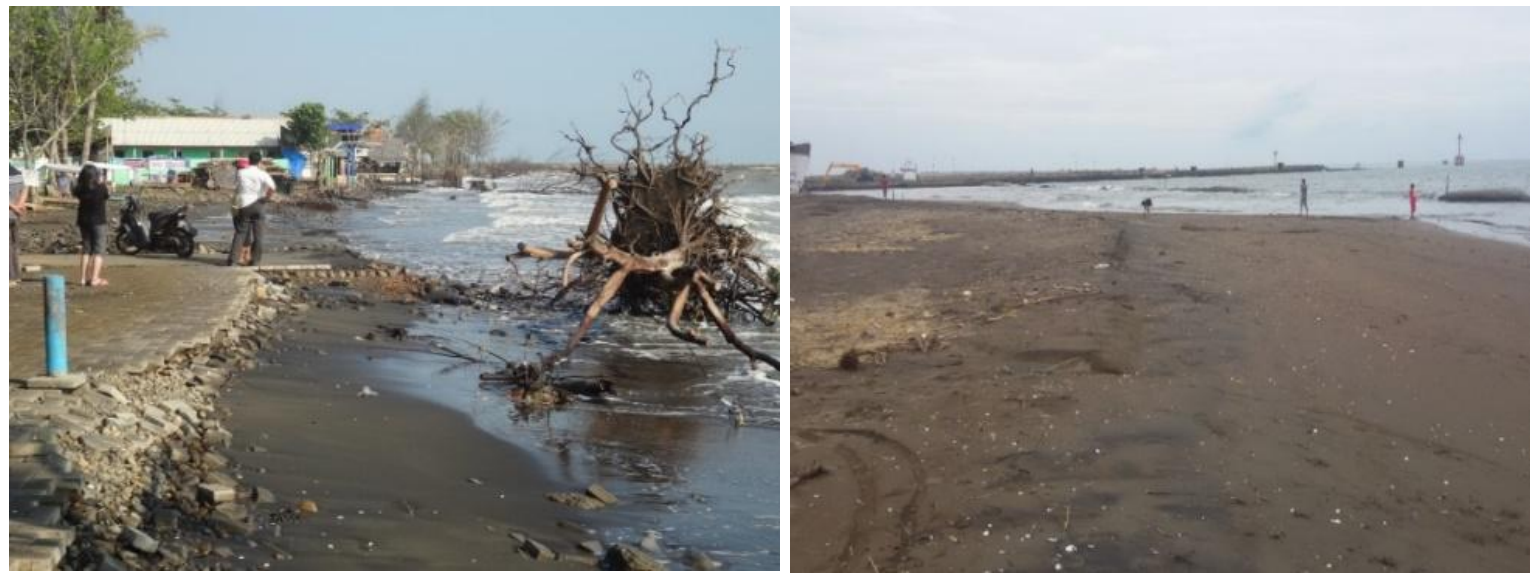

Fig. 6. Sigandu Beach, Before and After LCB Installation (Sulaiman et.al.,2015)

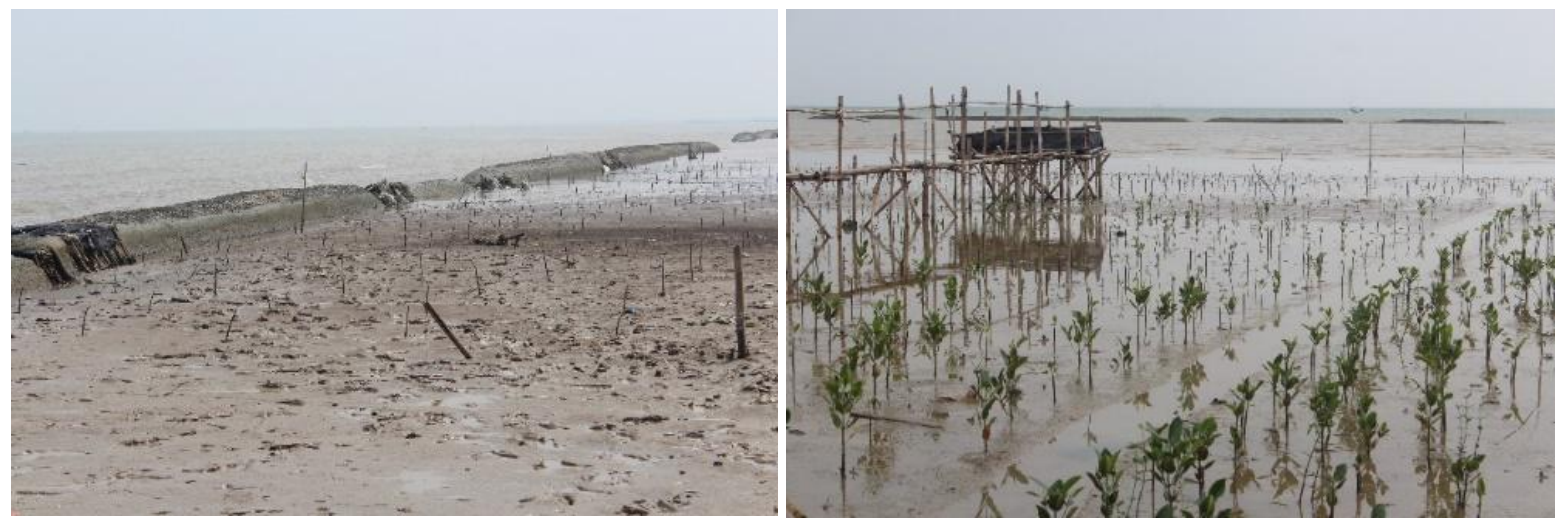

Fig.7. Sedimentation Behind LCB at Pasir Putih Beach, Karawang (MMAF, 2016) 


\subsection{Dimension of geotextile tube}

The geotextile tube used in LCB prototypes is a large sack made of non-woven geotextiles, which, once filled with sand, will be shaped like a bolster pillow. The geotextile tube size used after the sand has a dimension of length, width and height of about $20 \mathrm{~m}, 2 \mathrm{~m}$, and $1.2 \mathrm{~m}$. In accordance with the height, the geotextile tube type works well as an LCB structure for a maximum coastal depth of $2 \mathrm{~m}$. For deeper water conditions, for a depth of about 4-5 m, two stacking geotextile tubes may be used with the formation of mounting as shown in Figure 8 . Alternatively, for deeper waters can be used sand filled megacontainer with a height dimension of $3 \mathrm{~m}$ and a length of about $20-60 \mathrm{~m}$.

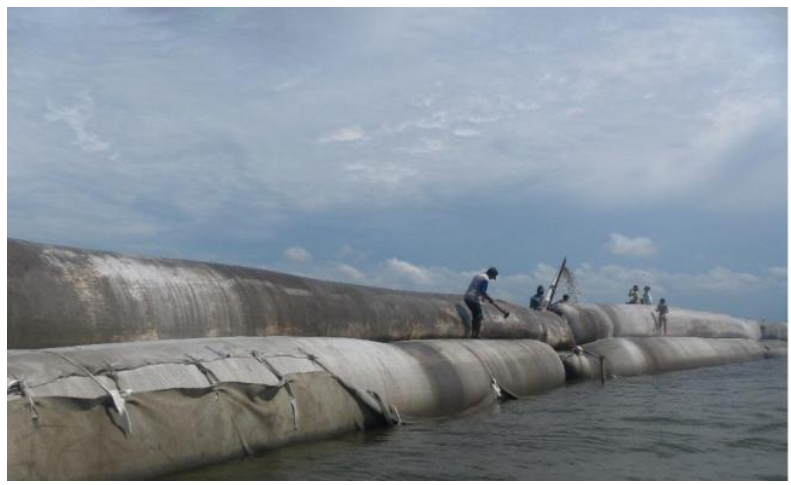

Fig. 8. Two stacking geotextile tubes at Pusong beach, Aceh (Sulaiman et.al., 2012)

\subsection{Advantages use of LCBs}

In terms of elevation and dimensions, the use of LCB has some advantages, namely (1) aesthetically, LCB does not obstruct the view towards the sea, because it is installed at a depth below the high water level, but when the LCB recedes can appear to the surface; (2) the wave is not completely obstructed so that the coastal response behind the LCB is relatively uniform in the long shore direction, (3) The wave energy behind the LCB has been reduced so that the waters behind it are safe for swimming, and (4) the LCB-generated impact is less than Conventional breakwater, therefore LCB is more environmentally friendly (RCWR, 2016). With LCB elevation lower than conventional breakwater, the shoreline change process and Tombolo or salient formation will be slower than conventional breakwater. 


\section{Conclusion and Recommendation}

\subsection{Conclusion}

The Successful in handling coastal erosion using geotextile tube LCB is indicated by the formation of new coastlines behind the structure. This success is supported by proper technical planning taking into account the characteristics of the coast. Coastlines that were previously eroded, in less than a year, have formed new beaches with large, thick sedimentary deposits.

Planning of the LCB's layout, either vertically or horizontally is crucial and determines its success in protecting and rehabilitating the coast. Vertical layout is related to the elevation position of LCBs crest relative to mean sea level. In addition, horizontal layout is related to the distance from the beach, the length of the structure, and the width of the gap.

In addition to its fuction as a wave absorber, geotextile tube LCBs act as sediment catchers and retaining sediments. The sediment transported by waves and settles behind the structure, continuously settles and forms a new coastline called salient and at some points the sediment is connected or merged with the structure called as tombolos. Sediment source that accumulated behind LCBs, coming from offshore-onshore transport and a longshore transport. Applying a space or a gap among LCB structures contribute to the sedimentation processes behind the structure. In addition to the supply of sediments through wave overtopping, even at low tide periode, the sediment supply continues through the gap.

In contrast, unsuccessful application of LCB structures, caused by inaccuracies in the LCB placement. It results from the position of LCBs is too close to the beach. Similarly, the crest level of LCBs is too low which results in wave dissipating so small that it does not produce a relatively quiet situation behind the structure that allows the sedimentation processes to occur. LCBs made of geotextile tubes are designed as a coastal protection. Coastal rehabilitation through LCB sructures will be more effective when combined with coastal vegetation. The combination of geotextile tube LCB as a wave energy absorver and coastal vegetation behind it will drive the sedimentation processes and accelerate coastal changes towards the sea. In its development, coastal vegetation such as mangrove will serve as a natural protector against extreme conditions in coastal areas. 


\subsection{Recommendation}

In order to have optimize configuration of $\mathrm{LCB}$, it is strongly recommended to carry out the model test in labboratory expertiment either in physical or numerical simulation. To avoid structural deformation and extend the life of structures, it is necessary to install bamboo piles and rafts; The need for proper LCB positioning from the coast; And the need for an armor layer on the outside of the geotextile tube.

LCB structure will experience local scour on the front and rear legs of the structure, it is necessary to install foot protector both in front and behind the structure.

\section{Acknowledgements}

The authors are grateful to both individuals and institutions over the data, information, and materials so that this paper can be arranged. My thanks go to the Direktorat Jenderal Pengelolaan Ruang Laut, Direktorat Pendayagunaan Pesisir, Ministry of Marine and Fisheries Affair; Director of Research Center for Water Resources; Chief of Experimental Station for Coastal Engineering; for the opportunity and support to complete this paper.

\section{References}

[1] Alvarez, E., R. Rubio, and H. Ricalde (2006). Shoreline Restored with Geotextile Tubes as Submerged Breakwaters, Geosynthetics Magazine, Volume 24, Nimber 3, pp 1-8.

[2] Ahmad B., M. Ismanto, S. Miftakhudin, and D.M. Sulaiman (2015). Coastal Erosion and Tidal flood Countermeasuring at Pekalongan Beach, in Proc. Annual Meet of 32 nd HATHI, Malang, Indonesia.

[3] Google Earth (2017). http://www.googleearth.com/Java, (down load June 15 , 2017).

[4] Hanson H. and N.C. Kraus (1990). Shoreline Response to a Single Transmissive Detached Breakwater, in Proc. 22nd Coastal Engineering Conf. ASCE. The Hague.

[5] Ministry of Marine Affairs and Fisheries (2016). Monitoring of Coastal Belt along the North coast of Java, (Jakarta, Indonesia.

[6] Research Center for Water Resources (2017). Draft Guidelines for Planning and Design of Low-Crested Breakwaters, Concensus Meeting, Bandung, Indonesia.

[7] Sulaiman, DM. (2012). Beach Rehabilitation Using Geotextile Tubes LCBs at Tanjung Kait Beach Tangerang, J.Keairan, Vol.2. No.2, Dessember, 2012. 
[8] Sulaiman, DM. (2014). "Piling-up and Current pattern behind segmented low-crested breakwaters", Doctoral Dissertasion, Graduate Program Prahyangan Catholic University, Bandung, Indonesia.

[9] Sulaiman, DM., H. Bachtiar, and A.Taufiq (2015). Beach profile changes due to lowcrested breakwaters at Sigandu Beach North Coast of Central Java, in Proceedia Engineering, 8th International Conference on Asian and Pacific Coasts, Elsevier, Volume 116, pages 510-519.

[10] Sulaiman, DM., S.S. Effendi, R. M. Azhar, and Suprapto (2016). Coastal restoration using segmented LCBs: Case study Sigandu beach, Batang, Central Java Province, Proc. of 33rd Indonesian Hydraulics Engineering Conference, Semarang, Indonesia. 